\title{
Factors Influencing the Creation of a Positive Climate in Natural Science Lessons from the Perspective of Pupils
}

\author{
Helena Grecmanová ${ }^{1,2}$, Dalibor Gonda ${ }^{1 *}$, Eva Urbanovská ${ }^{1}$, Vlasta Cabanová ${ }^{1}$ \\ ${ }^{1}$ Faculty of Humanities at the University of Žilina, SLOVAKIA \\ ${ }^{2}$ Department of Sociology, Andragogy, and Cultural Anthropology, Faculty of Arts, Palacky University in Olomouc, CZECH \\ REPUBLIC
}

Received 6 March 2020 - Accepted 28 April 2020

\begin{abstract}
A positive teaching climate has an important impact on pupils' attitude to learning subjects. The object of our research was to identify the factors affecting the climate of science subjects teaching. The research sample consisted of 454 primary and secondary school pupils. A questionnaire with 26 items was used as a research tool. Obtained data were subjected to factor analysis with loading factor of 0.45 . Based on our research, four factors with a statistically significant impact on the climate of natural science subjects teaching was identified. At the same time, it was found that neither sex nor age of pupils has a statistically significant effect on the climate perception of natural science subjects teaching.
\end{abstract}

Keywords: pupil, science subject, teaching climate, factor analysis

\section{INTRODUCTION}

Teaching is becoming one of the key concepts for people involved in teaching theory as well as for teachers themselves. Both educators and psychologists are looking for an answer to the question of how to influence pupils to learn effectively and at the same time to learn what they need for their future profession and personal development. Based on the latest knowledge about the functioning of the human brain, learning can be defined as the formation of synapses (neural networking) and thus the creation of neural networks or as a change in the existing way of neural networking (Moser, 2011). According to Sylvester (1995), emotions are also very important when processing information in the brain. On the basis of this knowledge, the need to create an appropriate climate in the classroom during classes is at the forefront. Because the emotions associated with knowledge affect the brain setting against learning individual subjects (Dweck, 2006). The mind setting more or less determines the learning climate. Empirical research on instruction has identified components of effective teaching that generally support student learning processes (Seidel \& Shavelson, 2007): goal clarity, teacher support, and positive learning climate.
According to Anderson (1982), the teaching climate is defined as the continuing quality in teaching, which is characterized by certain characteristics that pupils can experience, and which can influence their behaviour. Pupils often experience a "reluctance" to learn mainly science subjects, and this "reluctance" (closed mind) results in very poor progress in these subjects (Blackwell et al., 2007).

According to Anderson (1982), pupils first experience teaching individually, but later on, interactions and shared experiences occur. The learning climate is becoming a collective experience. Climate as a collective psychological situation affects the behaviour of pupils. According to Cohen (2006), there is a close link between effective teaching and a positive teaching climate. In a favourable climate, pupils are more inclined to tackle new tasks, seeing themselves as more capable of managing social conflicts. However, a positive teaching climate affects not only the cognitive process. Studies have shown that school climate is related to all aspects of school life including leadership style, community sense, expectations for students, an ethos of caring, and a variety of student outcomes (Goddard, Sweetland, \& Hoy 2000; Gottfredson, Gottfredson, 


\section{Contribution to the literature}

- Science subjects are still considered uninteresting by pupils and distant from everyday life.

- According to our findings, teachers could reverse this trend by creating a positive climate for science subjects teaching.

- Pupils are motivated to learn science subjects by an avid teacher, who can clearly set the rules of work and apply them fairly.

Payne, \& Gottfredson, 2005; National Research Council, 2003; Sweetland \& Hoy, 2000).

\section{Aims of the Research}

The aim of the research was to identify the factors influencing the creation of a positive climate of science teaching in the condition of the Slovak school system. At the same time, a questionnaire was adapted to the conditions of the Slovak school environment.

\section{METHODS}

\section{Research Sample}

The research sample consisted of 454 pupils of Slovak schools. Pupils from primary schools $(\mathrm{n}=378)$ and secondary schools $(n=76)$ were included in the research. The age of respondents ranged from 10 to 18 years. Among the respondents there were 269 girls, which represents $59.25 \%$ and 185 boys, which represents $40.75 \%$ of the research sample. The selection of pupils was intentional as one of the partial objectives was to adapt the existing questionnaire to the conditions of the Slovak Republic. According to Hertzog (2008), deliberate selection is appropriate for carrying out pilot studies. It is also appropriate to use a deliberate selection of respondents to adapt and validate the research tool (Cohen, Manion, \& Morrison, 2007).

\section{Research Tool}

A questionnaire was used as a research tool. The basis for the questionnaire was an existing questionnaire created and verified in Czech Republic.

\section{Procedure}

The research team first adapted the research tool to the conditions of the Slovak education system (Kubjatko, et al., 2018). All respondents were informed by the test administrator about the research objective. At the same time, they were assured that this was an anonymous data collection, solely for research purposes. Respondents responded to individual items using a 5point Likert scale on the determination of the school climate on science subjects. Respondents were asked to indicate one of the following for each item: never, sometimes, often, usually or always. All questionnaires were filled in correctly and the data were included in the analyses. Respondents' answers were coded as follows: never -1 , sometimes -2 , often - 3 , usually - 4 , always -5 . The obtained data were statistically processed by factor analysis using Statistica 10.0.

\section{RESULTS}

The data obtained were analysed by the KaiserMayer-Olklin test and the Bartlett sphericity test. The result of KMO was a coefficient of 0.86 , the value of which we interpret as a high suitability for the use of factor analysis (Cerny \& Kaiser, 1977). The value of Bartlett's sphericity test was $\chi 2=738.51(p<0.001)$, thus rejecting the null hypothesis and, as with KMO, justifying the use of factor analysis of the data obtained. Subsequently, the obtained data were subjected to confirmatory factor analysis with Varimax rotation. On the one hand, the factor analysis divided the questionnaire items into four factors: FA 1: Internal teacher passion, efforts to overall pupil development, FA 2: Social aspects of teaching, FA 3: Relationship to authority, FA 4: Existence and adherence to rules. These factors (dimensions) account for $47.36 \%$ of the total variance. The first dimension explains $28.29 \%$ of the total variance, thus adhering to the rule that the 1st dimension must explain at least $20 \%$ of the total variance (Reckase, 1979). At the same time, the factor analysis used ensured construct validity. The factor score was 0.45 . The same value was used in the research by Voepel-Lewis (2010) where loading factors of 0.45 or greater were considered acceptable the accuracy and reliability of the research tool was verified by Cronbach's alpha value. According to (Cronbach, 1951; Nunnally, 1978), the limit value is considered to be $a=0.70$. The Cornbach alpha value of the used research instrument is $\alpha=0.89$, indicating the accuracy and reliability of the research instrument.

For individual factors, the Cornbach alpha values ranged from 0.58 to 0.88 , which declares the reliability of the individual factors. As Ferketich (1991) and Kline (1993) stated, when dividing items in a questionnaire into dimensions, the alpha value for dimensions is expected to decrease, with the limit for the reliability of each dimension being determined as $\alpha=0.50$.

The results of the factor analysis are shown in Table 1.

Item 6 "Tasks are appropriate to what I have learned" and item $<24$ "The teacher focuses only on the particular topic when teaching" were eliminated from further analysis as their factor score was less than 0.45 . 
Table 1 . The results of factor analysis

\begin{tabular}{|c|c|c|c|c|c|}
\hline ITEM & $a$ & FA 1 & FA 2 & FA 3 & FA 4 \\
\hline FA1 Inner passion of the teacher, efforts to develop the pupil overall & 0.88 & & & & \\
\hline 8. I can apply good ideas in the classroom. & & 0.478 & 0.259 & 0.329 & 0.093 \\
\hline 9. The teacher supports me when I am interested in the subject. & & 0.646 & 0.024 & 0.186 & 0.195 \\
\hline 10. If I cannot perform my learning tasks, I get help. & & 0.570 & 0.252 & 0.103 & 0.266 \\
\hline 13. The teacher teaches interestingly and enthusiastically. & & 0.690 & 0.129 & 0.167 & 0.115 \\
\hline 14. The teacher will explain where and when to use what we learned & & 0.605 & 0.327 & 0.138 & 0.099 \\
\hline 15. The teacher always says in what profession the curriculum can be used. & & 0.582 & 0.421 & 0.157 & 0.016 \\
\hline 16. The teacher uses visual aids and examples & & 0.593 & 0.111 & 0.010 & 0.218 \\
\hline 17. The results of my work are fairly rated in the classroom. & & 0.610 & -0.20 & 0.157 & 0.355 \\
\hline $\begin{array}{l}\text { 22. Before we move on to the new curriculum, the teacher asks us what we already know about the } \\
\text { new topic. }\end{array}$ & & 0.513 & 0.228 & -0.018 & 0.106 \\
\hline 23. The teacher is happy about our success in teaching process. & & 0.669 & 0.123 & 0.133 & 0.104 \\
\hline 25. The teacher keeps my attention in his way of teaching. & & 0.535 & 0.226 & 0.105 & 0.190 \\
\hline FA 2: Social aspects of teaching & 0.67 & & & & \\
\hline 11. When I complete my tasks faster than others, my teacher will give me another job. & & -0.06 & 0.635 & 0.033 & 0.352 \\
\hline 12. Teaching takes place also outside school. & & 0.099 & 0.723 & -0.033 & 0.017 \\
\hline 20. In performing tasks we work in groups. & & 0.268 & 0.642 & 0.112 & -0.020 \\
\hline 21. We are encouraged to discuss the progress of the tasks with classmates in the classroom. & & 0.383 & 0.604 & 0.150 & 0.044 \\
\hline FA 3: Relationship to authority. & 0.58 & & & & \\
\hline 1. I will give my opinion to the teacher without fear. & & 0.275 & 0.019 & 0.697 & -0.034 \\
\hline 2. I have to show my opinion to the teacher. & & -0.20 & 0.108 & 0.618 & 0.270 \\
\hline 7. Domestic questions for management training without prejudice. & & 0.202 & -0.05 & 0.570 & 0.227 \\
\hline 18. I feel fine before testing. & & 0.290 & 0.206 & 0.633 & -0.225 \\
\hline FA 4: Existence and rules keeping & 0.61 & & & & \\
\hline 3 The work rules are clearly defined. & & 0.181 & 0.132 & 0.066 & 0.630 \\
\hline 4. The assigned tasks must be done accurately and reliably. & & 0.141 & 0.037 & 0.012 & 0.685 \\
\hline 5. The assigned tasks are continuously checked. & & 0.141 & 0.302 & 0.046 & 0.576 \\
\hline 19. I am tested how I understand the curriculum. & & 0.374 & -0.09 & 0.198 & 0.456 \\
\hline 26. The teacher answers questions about the curriculum. & & 0.404 & -0.20 & -0.027 & 0.454 \\
\hline Personal number & & 7.356 & 2.063 & 1.586 & 1.311 \\
\hline \% variance & & 28.29 & 7.93 & 6.10 & 5.04 \\
\hline
\end{tabular}

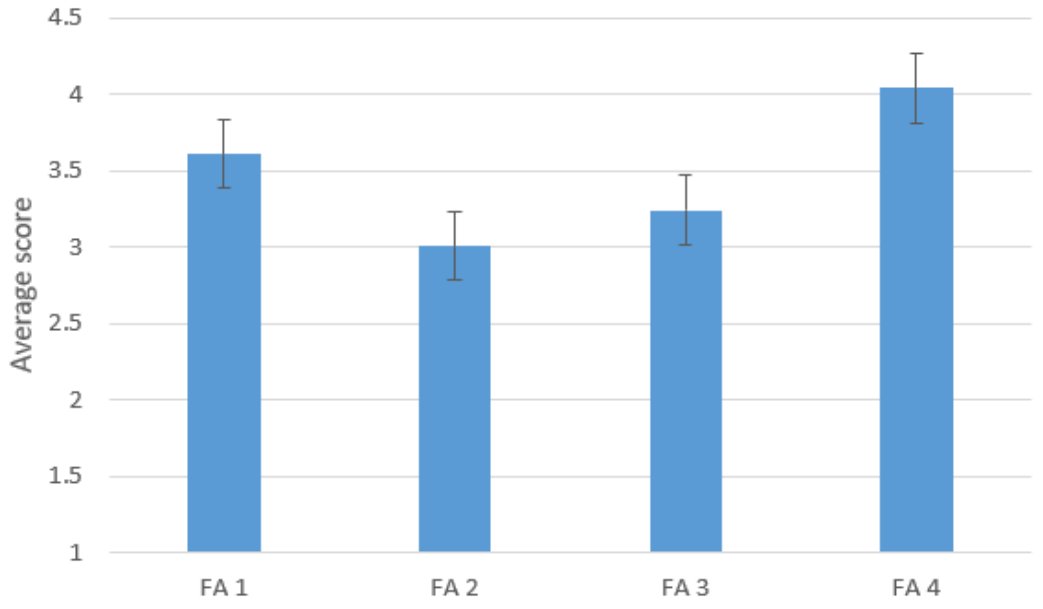

Figure 1. Average score of each factor

The data obtained, divided by factor analysis into individual dimensions, were evaluated based on the average total score of the items in the dimensions. The average score makes it possible to determine the perception of the climate by pupils on natural science subjects. If the average score is in the range of $\langle 2.5,3.25\rangle$ it is possible to speak of a neutral perception of climate on natural science lessons. At a score below 2.5 we speak of a rather negative perception of the climate and at a score above 3.25 we speak of a rather positive perception of the climate.

The overall average score obtained from the survey respondents was $\mathrm{x}=3.42(\mathrm{SD}=0.76)$. On the basis of this value we can speak of a rather positive climate on natural science lessons. Four factors have been identified by factor analysis, which have an impact on the climate level of natural science lessons, the average score of which is in Figure 1.

Figure 1 shows that FA 4 "Existence and keeping to the rules" have a significant positive impact on pupils' overall perception of natural science lessons $(x=4.04 \mathrm{SD}$ $=1.19$ ). FA 1 also has a slightly positive impact on the climate level. FA 3 "The relationship to authority" was assessed by pupils as a climate-neutral factor $(x=3.24$ $\mathrm{SD}=0.72)$. FA 2 "Social aspects of teaching" with an average score of $x=3.01(\mathrm{SD}=0.53)$ can be interpreted as a factor with a neutral impact on climate level. It is also the factor with the lowest average score achieved. In 


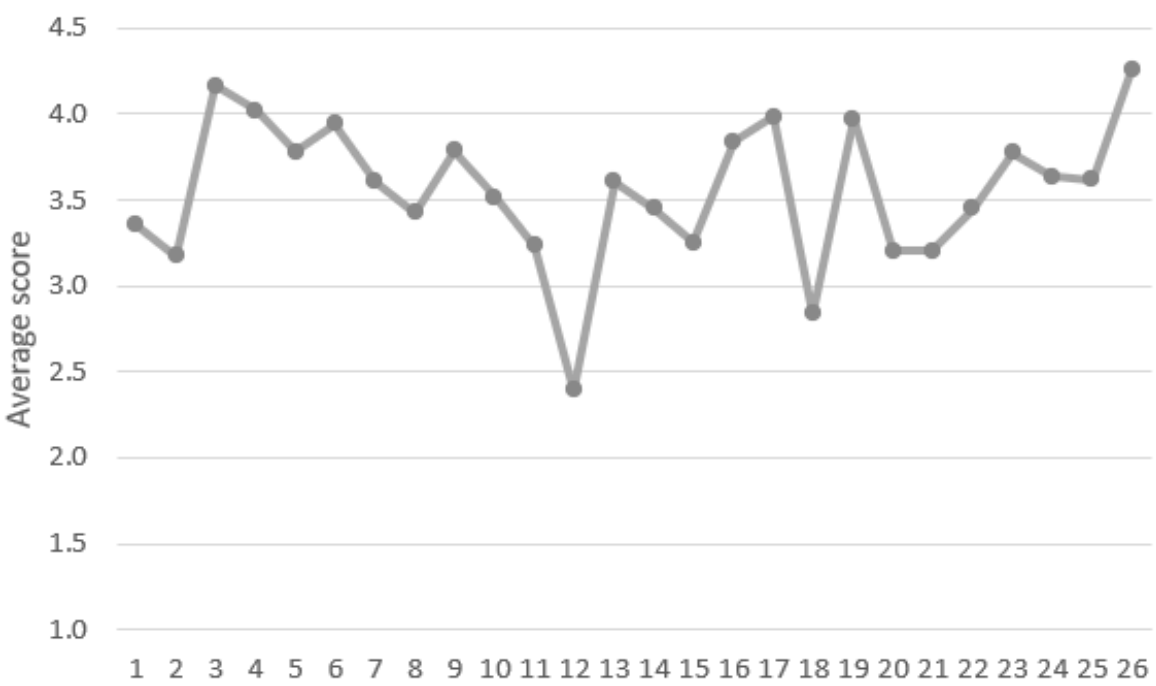

Figure 2. Average score for each item

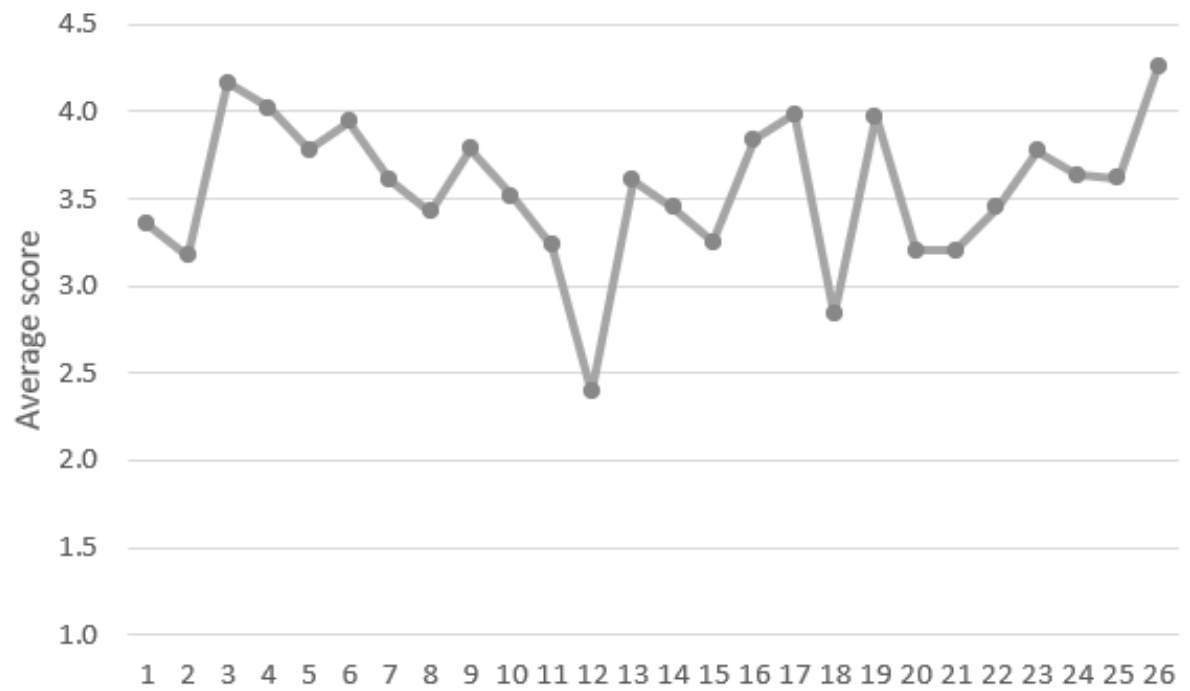

Figure 3. Average scores of boys and girls for each factor

comparison with the research (Kubiatko et all., 2018), the same factors affecting the climate of science teaching were found in principle. The distribution of items was similar. The difference, however, is that in our research, the teacher impact factor was divided into two factors (FA 1 and FA 3).

Figure 2 shows the average score for each item. The highest score $(x=4.26 \mathrm{SD}=1.04)$ was achieved in item 26 (Teacher answers pupils' questions about curriculum). Items 3 (The rules of work are clearly defined in the classroom), 4 (The tasks I have to perform accurately and reliably), 17 (The results of my work are fairly evaluated in the classroom) and 19 (I am tested as I understand the curriculum.). The lowest average score $(x=2.39 \mathrm{SD}=1.33)$ was reached in item 12 (Teaching takes place outside school). It is also the only item that can be interpreted as a negative perception based on an average score. A relatively low score $(x=2.83 \mathrm{SD}=1.33)$ was also achieved in item 18 (I feel fine before testing).

We were also interested in whether gender perception (Figure 3) and school type (Figure 4) affect pupils' perception of the climate. We used analysis of variance - the ANOVA test (single factor) to determine the impact of these variables on the teaching climate.

The effect of gender on classroom climate perception in natural science lessons was shown to be statistically insignificant $(\mathrm{F}=0.63 ; \mathrm{p}=0.426)$. Also, statistically insignificant $(\mathrm{F}=0.99 ; \mathrm{p}=0.32)$ is the impact of the school type on the perception of the climate in natural science lessons.

The analysis of the average score for each item (Figure 5) also suggests the same perception of individual variables of questioner on the class climate considering the gender. The only noticeable difference was noted for item 18 (I feel fine before testing). Boys had an average score of $\mathrm{x}=3.13$ and girls $\mathrm{a} x=2.58$.

Figure 6 shows relatively large differences in the average score for each item. Secondary school pupils have a more negative assessment of items 11 (When I complete tasks faster than others, my teacher assigns me another job.), 20 (We work in groups when doing tasks.), 21 (We are encouraged to discuss in class with classmates on the progress of tasks.) 
5

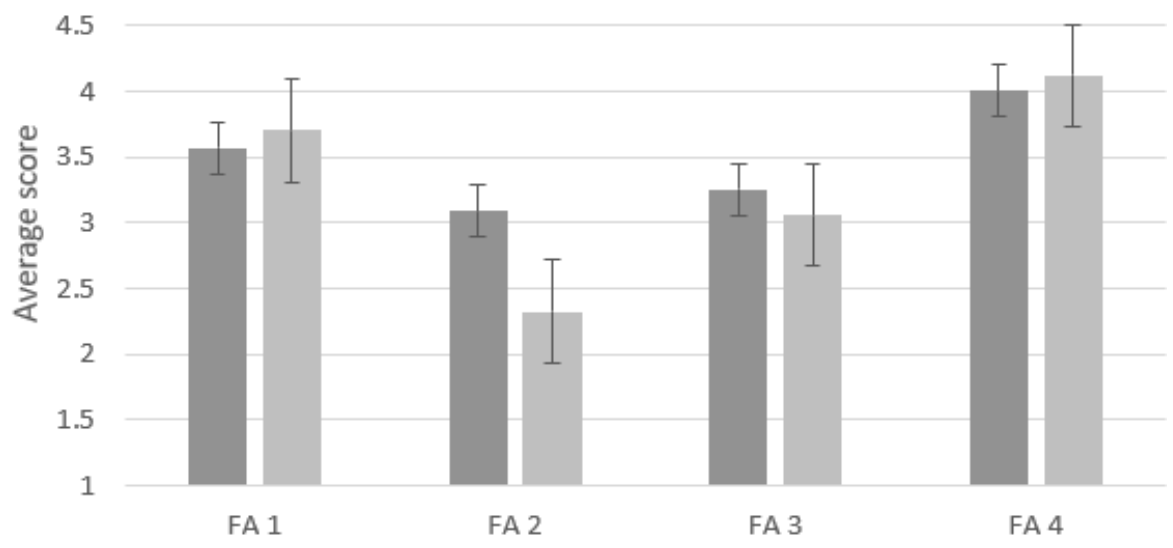

a elementary school pupils a secondary school students

Figure 4. Average secondary and primary scores for individual factors

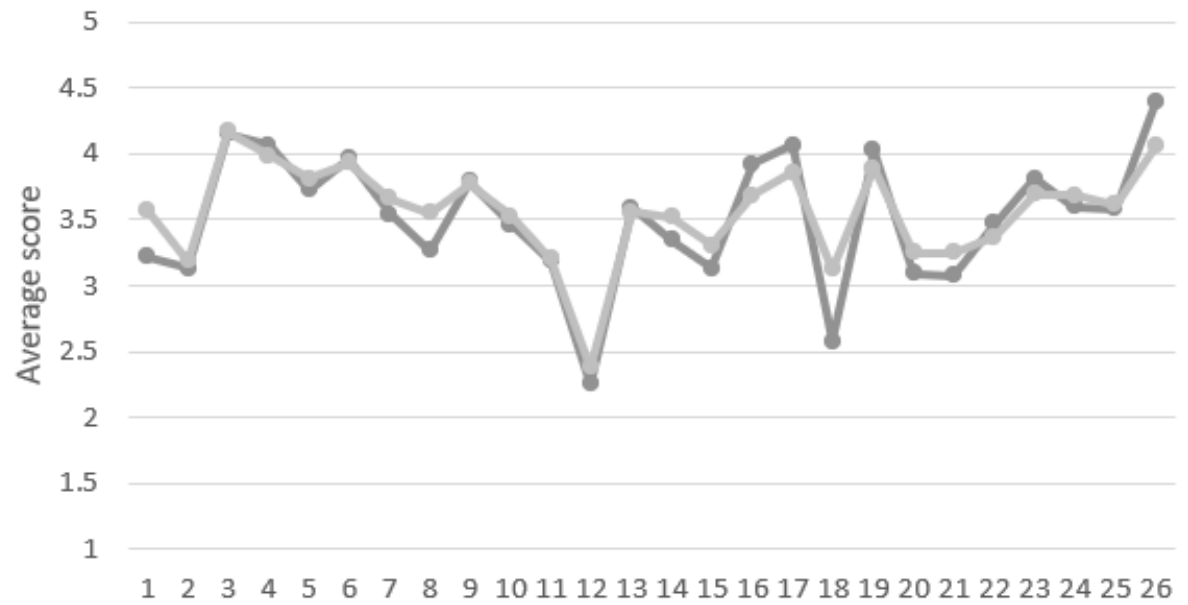

Figure 5. Average score for each item by gender

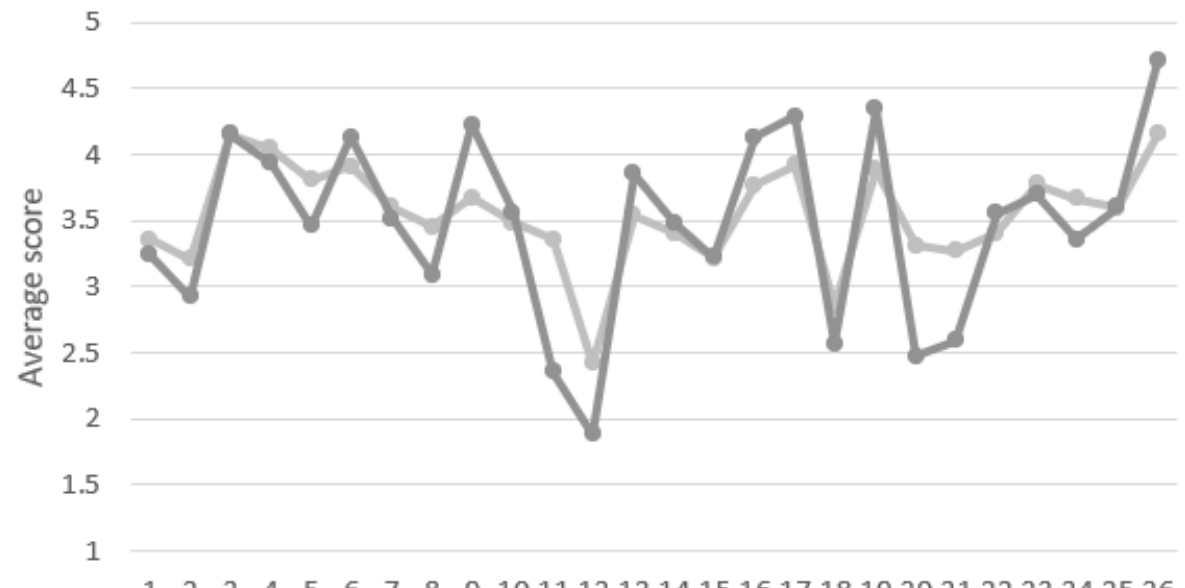

Figure 6. Average score for each item by gender

$\longrightarrow$ girls $\longrightarrow$ boys

$\begin{array}{llllllllllll}1 & 2 & 3 & 4 & 5 & 6 & 7 & 8 & 9 & 1011 & 121314151617181920212223242526\end{array}$

—elementary school pupils $\quad \longrightarrow$ secondary school students 
The overall average score obtained from the data of our research respondents was $\mathrm{x}=3.42(\mathrm{SD}=0.76)$, which, according to Papanastasiou and Papanastasiou (2004) research, would indicate a rather positive attitude of respondents to natural science attitudes.

\section{DISCUSSION}

Through a detailed analysis of the identified factors that affect pupils' perception of the learning climate, we have found that the key factor creating the learning climate is the influence of the teacher. Factor FA 4 "The existence and rules keeping", with a relatively significant impact on the climate in the natural science lessons, indicates to the personality of the teacher who is able to clearly define the rules of work on the subject and apply them fairly. Similarly, the positive impact factor FA 1 "The internal passion of the teacher, the effort to develop the pupil overall", indicates the ability of the teacher by his / her enthusiasm for the curriculum and the pupil's interest in being a motivator for learning. Our findings correspond to the results of other researchers Similarly, Fulbeck and Subert (2010) found that the teacher had a clear influence on pupils' attitude to natural science subjects and on their success in these subjects. According to our findings, the teacher also has a key role to play in creating climate in natural science lessons. A significant influence of the teacher's personality on the overall relationship of pupils to natural science is already known from researches in 1960 (Flanders, 1960). It is interesting to note that FA 2 Social aspects of teaching have a neutral impact on the climate of science teaching. We conclude that pupils do not attach the utmost importance to working together during their lessons. This finding points to the fact that the social aspect of teaching is not as important to pupils' views as several experts (e.g. Lave and Wenger, 1991, Powell and Kalina, 2009) have pointed to the importance of social learning conditions and emphasizing social interaction. in learning. Our findings on the social aspect of science teaching could be the subject of further research because, according to researches Lave (1991), Astin (1991) and Rio-Fernandez (2017), the largest share of pupil's personal development and learning performance is interaction with other pupils. The impact of gender on the climate of natural science subjects has not been demonstrated, which is consistent with other research findings (e.g. Fischer, 2003). The impact of the school type on climate perception is less relevant considering the low number of secondary school respondents compared to primary school respondents.

\section{CONCLUSION}

Recently, pupils' interest in natural science subjects has been decreasing worldwide (Ramsden, 1998), which is confirmed not only by foreign research but also by domestic research. In Slovakia, a number of school reforms contributed to the decline in interest in science subjects, as a result of which the hourly rate of science subjects at both primary and secondary schools dropped significantly. The most significant decrease was in the number of hours of physics lessons by up to $50 \%$. Teaching science is often aimed at learning the lessons and the various facts. The lack of interest of primary school pupils in natural science subjects is shown in local studies. Also, for this reason science subjects are still considered by pupils to be uninteresting and distant from everyday life. According to our findings, by creating a positive climate in teaching natural science subjects, teachers could change this trend and through a positive relationship with natural science subjects, increase interest in studying at technical universities. Nolen (2003) surveys have found that a positive climate on natural science subjects has had an impact on choice of elective subjects. It can be concluded that a positive climate made by teacher has some influence on the choice of pupils' future vocation.

Due to the good climate that a teacher can induce in science teaching, it is possible to increase interest in studying at technical universities where there is currently a shortage of students. Nowadays, employers highly appreciate their ability to work in a team. Therefore, it is necessary to increase the positive perception of social aspects of teaching, not only on science subjects.

\section{REFERENCES}

Anderson, C. S. (1982). The Search for School Climate: A Review of the Research. Review of Educational Research, 52(3), 368-420. https://doi.org/10.3102/ 00346543052003368

Astin, A. (1991). What Really Matters in General Education: Provocative Finding from a National study of Student Outcome. Seattle.

Blackwell, L. S., Trzesniewski, K. H., \& Dweck, C. S. (2007). Implicit theories of intelligence predict achievement across an adolescent transition: A longitudinal study and an intervention. Child development, 78(1), 246-263. https://doi.org/ 10.1111/j.1467-8624.2007.00995.x

Cerny, C.A., \& Kaiser, H.F. (1977). A study of a measure of sampling adequacy for factor-analytic correlation matrices. Multivariate Behavioral Research, 12(1), 43-47. https://doi.org/10.1207/ s15327906mbr1201_3

Cohen, J. (2006) Social, Emotional, Ethical, and Academic Education: Creating a Climate for Learning, Participation in Democracy, and Well-Being. Harvard Educational Review: July 2006, 76(2), 201237. https://doi.org/10.17763/haer.76.2.j4485 $4 \times 1524644 \mathrm{vn}$ 
Cohen, L., Manion, L. \& Morrison, K. (2007). Research methods in education (6th ed.). Routledge: Oxford. https:/ / doi.org/10.4324/9780203029053

Cronbach, L. J. (1951). Coefficient Alpha and the internal structure of tests. Psychometrika, 16(3), 297-334. https:/ / doi.org/10.1007/BF02310555

Dweck, C. S. (2006). Mindset: The new psycholody of success. New York: Ballantine Books.

Ferketich, S. (1991). Focus on psychometrics. Aspects of item analysis. Research in Nursing $\mathcal{E}$ Health, 14(2), 165-168. https:/ / doi.org/10.1002/nur.4770140211

Fernandez-Rio J, Cecchini JA, Méndez-Gimenez A, Mendez-Alonso D, \& Prieto JA (2017). SelfRegulation, Cooperative Learning, and Academic Self-Efficacy: Interactions to Prevent School Failure. Front. Psychol., 8, 22. https://doi.org/ 10.3389/fpsyg.2017.00022

Fischer, B. (2003). Soziales Lernen an einer Reformschule. Evaluationsstudie über Unterschiede von Sozialisationsprozessen in Reform- und Regelschulen. Weinheim, München: Juventa.

Fulbeck, E. S., \& Subert, A. N. (2010). Teacherś attitudes, behaviors $\mathcal{E}$ student achievement. Bulder, COL: Procomp.

Goddard, R. D., Sweetland, S. R., \& Hoy, W. K. (2000). Academic emphasis of urban elementary schools and student achievement in reading and mathematics: A multilevel analysis. Educational Administration Quarterly, 36, 683-702. https://doi.org/10.1177/00131610021969164

Gottfredson, G. D., Gottfredson, D. C., Payne, A. A., \& Gottfredson, N. C. (2005). School climate predictors of school disorder: Results from a national study of delinquency prevention in schools. Journal of Research in Crime and Delinquency, 42, 412-444. https: / / doi.org/10.1177/0022427804271931

Hertzog, M. A. (2008). Considerations in determining sample size for pilot studies. Research in Nursing and Health, 31(2), 180-191. https://doi.org/10.1002/ nur. 20247

Kalina, C., \& Powell, K. C. (2009). Cognitive and social constructivism: Developing tools for an effective classroom. Education, 130(2), 241-250.

Kline, P. (1993). The Handbook of Psychological Testing. Routledge: London.

Kubiatko, M., Grecmanova, H., Balatova, K., et al. (2018). Validity and reliability analyses for the climate of science subjects research tool. Open Access J Sci., 2(4), 259-263. https://doi.org/10.15406/oajs.2018. 02.00084
Lave, J. (1991). Situated Learning in Communities of Practice. I LB Resnick, JM Levine och SD Teasley (red.).

Lave, J., \& Wenger, E. (1991). Situated learning: Legitimate peripheral participation. Cambridge university press. https:/ / doi.org/10.1017/CBO9780511815355

Moser, J. S., Schroder, H. S., Heeter, C., Moran, T. P., \& Lee, Y. H. (2011). Mind your errors: Evidence for a neural mechanism linking growth mind-set to adaptive posterror adjustments. Psychological Science, 22(12), 1484-1489. https:/ / doi.org/10.1177 /0956797611419520

National Research Council (2003). Engaging schools: Fostering high school students' motivation to learn. Washington, DC.: National Academies Press.

Nolen, S. B. (2003). Learning Environment, Motivation, and Achievement in High School Science. Journal of Research in Science Teaching, 40(4), 347-368. https://doi.org/10.1002/tea.10080

Nunnally, J. C. (1978). Psychometric theory (2nd ed.). New York: McGraw-Hill.

Papanastasiou, C. \& Papanastasiou, E. C. (2004). Major influences on attitudes toward science. Educational Research and Evaluation, 10(3), 239-257. https:/ / doi.org/10.1076/edre.10.3.239.30267

Reckase, M. D. (1979). Unifactor Latent Trait Models Applied to Multifactor Tests: Results and Implications. Journal of Educational Statistics, 4(3), 207-230. https:/ / doi.org/10.2307/1164671

Seidel, T., \& Shavelson, R. J. (2007). Teaching effectiveness research in the last decade: role of theory and research design in disentangling metaanalysis results. Review of Educational Research, 77, 454e499. https://doi.org/10.3102/0034654307310 317

Sweetland, S. R., \& Hoy, W. K. (2000). School characteristics and educational outcomes: Toward and organizational model of student achievement in middle schools. Educational Administration Quarterly, 36, 703-729. https://doi.org/10.1177/ 00131610021969173

Sylvester, R. A. (1975). Celebration of Neurons. An Educators Guide to theHuman Brein [on-line]. 2000. [cit. 2003-27-01] Retrieved from http:/ / www.ascd. org/readingroom/books/ sylwester95book.html

Voepel-Lewis, T., Zanotti, J., Dammeyer, J. A., \& Merkel, S. (2010). Reliability and validity of the face, legs, activity, cry, consolability behavioral tool in assessing acute pain in critically ill patients. American journal of critical care, 19(1), 55-61. https:/ / doi.org/10.4037/ajcc2010624

\section{http://www.ejmste.com}

